\title{
Bio-Priming Using Indigenous Pseudomonas Fluorescens To Improve Local Upland Rice (Padi Gogo) Production Of Paebiu Kolopua And Pae Wuna Cultivars
}

\author{
Asri Razad*1, Gusti Ayu Kade Sutariati², Tresjia C Rakian³ ${ }^{3}$ Jendri Mamangkey ${ }^{4}$, \\ Marina Silalahi ${ }^{5}$ \\ ${ }^{1,2,3}$ Department of Agro technology, Faculty of Agriculture, Halu Oleo University, Kendari \\ Southeast Sulawesi, Indonesia \\ ${ }^{4,5}$ Department of Biology Education, Faculty of Education and Teacher Training, Universitas \\ Kristen Indonesia, Jakarta. J1. Mayjen Sutoyo No. 2, Cawang, Jakarta Timur13630, Jakarta, \\ Indonesia \\ * Corresponding author: \\ Email: razak_asri@yahoo.co.id
}

\begin{abstract}
.
Research was performed to evaluate the effect of biopriming technique using indigenous rhizobacteria in improving local upland rice from Southeast Sulawesi. Randomized group design was applied in this research using factorial pattern consisting of 2 factors. The first factor was upland rice cultivars consisting of 2 (two) levels of Paebiu Kolopua (V1) and Pae Wuna (V2) cultivars. Meanwhile, the second factor was rhizobacteria isolates, consisting of 4 (four) levels, those are without rhizobacteria treatment (R0), KNS11 isolate (R1), KLKU02 isolate (R2) and KNW11 isolate (R3). Research results indicated that interaction between Paebiu Kolopua cultivar and KLKU02 isolate treatment significantly affected plants height with $29.22 \%$ improvement and the amount of rice per panicle with $176.33 \%$ improvement compared to the control. Therefore, KLKU02 isolate can be recommeded as the best treatment to improve the production and outcome of local upland rice plant.
\end{abstract}

Keywords: Biopriming, paebiu kolopua, pae wuna, Pseudomonas fluorescens

\section{INTRODUCTION}

The current soil engineering scenario is entirely dependent on synthetic chemicals, which are responsible for some human health and environmental issues [1]. Biological seed treatment is the most effective method to protect seeds from soil-borne pathogens at early stage of plant development [2,3] and also effectively reduce the dependence on chemical fungicide for diseases management [4,5]. As a result, we must shift toward organic agriculture to resolve these challenges. The rhizosphere is a zone where plant and microbial interactions are mostly commensal and mutualistic, and it is affected by the root system [6]. Beneficial microorganisms that live in the rhizosphere have been studied extensively for their biological control and growth-promoting abilities. As a result, they are frequently employed as effective environmentally friendly insecticides and fertilizers. On the basis of their mechanisms of action, beneficial bacteria are classed as biofertilizers and biocontrol agents such as host 
growth promotion, antibiosis, parasitism, competition and host resistance enhancement for suppression of phytopathogens $[7,8]$.

Even under difficult conditions, bio-priming helps seeds germinate consistently [9]. Bio-priming, which combines seed priming with bacterial inoculation, is the most cost-effective, efficient, and straightforward strategy for increasing tolerance and establishing plant stands in harsh environments [10]. Seed bio-priming is an advanced and prominent technique used to persuade plant health and stress tolerance. Most importantly, this ecological approach protects the seeds against various seed and soil borne pathogens by suppressing incidence of a disease [11,12]. Some rhizobacteria are advantageous to crops and have affect plant development positively through various ways.Plant growth promoting rhizobacteria (PGPR) are bacteria that affect plant development positively through any method [13]. PGPR such as Azospirillum, Azotobacter, and Pseudomonas also have a great capacity to sustain plants under stressful situations [14]. Pseudomonas species are the most often used bacteria for promoting plant growth. Most plant growth-promoting bacteria, such as Pseudomonas aeruginosa, are susceptible to harsh environmental conditions and are unable to generate persistent spores to survive them [15].

Zahir et al. showed that drought stress on pea development might be mitigated by inoculating pea plants with rhizobacteria expressing ACC deaminase [13]. Efficacy varied at different moisture levels; P. fluorescens biotype G (ACC-5) showed the most promise at $25 \%$ field capacity, with inoculation resulting in the largest gains in fresh weight, root and shoot length, leaf number, and water usage efficiency. Gou et al. İn another project presented that the accumulation of choline and glycine betaine and improved leaf relative water content and dry matter weight under varying water deficitstress in maize by P. fluorescens YX2, Klebsiella variicola F2, Raoultella planticola YL2. Inoculation of P. fluorescens $\mathrm{P} 1$ and P. fluorescens P8 isolates are able to increase the tolerance towards water deficit stress, root growth, and Zea mays L. var saccharata production results [16]. Pseudomonas fluorescens SS101 memproduksi novel volatile organic compounds yang terdiri dari 13-Tetradecadien-1-ol, 2-butanone and 2-Methyl-n-1-tridecene [17]. P. fluorescens was shown as the most effective PGPR strain [18].

Southeast Sulawesi has many local upland rice cultivars spread in several regions, both land area and islands area. Several upland rice tupes have been cultivated ans succesfully grow and produce better in dry soil condition. Paebiu Kolopua cultivar (cultivated in South Konawe land area) shows the highest outcome among 24 local cultivars from Southeast Sulawesi [19], while Pae Wuna cultivar (cultivated in islands area) is one of tolerant cultivar towards drought [20]. However, it is unfortunate that the production of upland rice in Southeast Sulawesi in 2015 was low, of which productivity was only $2.70 \mathrm{ton} / \mathrm{ha}$. Southeast Sulawesi's upland rice productivity was lower than the national average, obtaining 3.34 ton/ha [21]. This was caused by several factors including the use of low quality seed and low soil fertility. Study concerning 
the integration between seed biopriming and indigenous rhizobacteria aiming to enhance the seed viability and vigor as well as solving the physiological issues on seeds of local upland rice is limited, therefore this research is important to be conducted in order to answer the issues of low productivity of upland rice.

\section{METHODS}

\section{Indigenous Rhizobacteria Isolate Source}

Local upland rice seed of Kolopua (local Konsel) and Pae Wuna (local Raha) cultivars, NPK fertilizer (15:15:15), indigenous rhizobacteria of $P$. fluorescens KNS11 (South Konawe), P. fluorescens KLKU02 (North Kolaka) and P. fluorescens KNW11 (Konawe) are isolates collection from Prof. Dr. Ir. Gusti Ayu Kade Sutariati, M.Si (Department of Agrotechnology, Faculty of Agriculture, Halu Oleo University).

\section{Research Design}

The experimental design applied was a randomized group design through factorial pattern of 2 factors. The first factor was upland rice cultivars consisting of 2 (two) levels of Paebiu Kolopua and Pae Wuna cultivars. Meanwhile, the second factor was rhizobacteria isolates, consisting of 4 (four) levels, those are without rhizobacteria treatment, KNS11 isolate, KLKU02 isolate and KNW11 isolate. The treatment was provided for 8 combinations, each was done for 3 times, concluding to 24 experimental units performed (Figure 1).

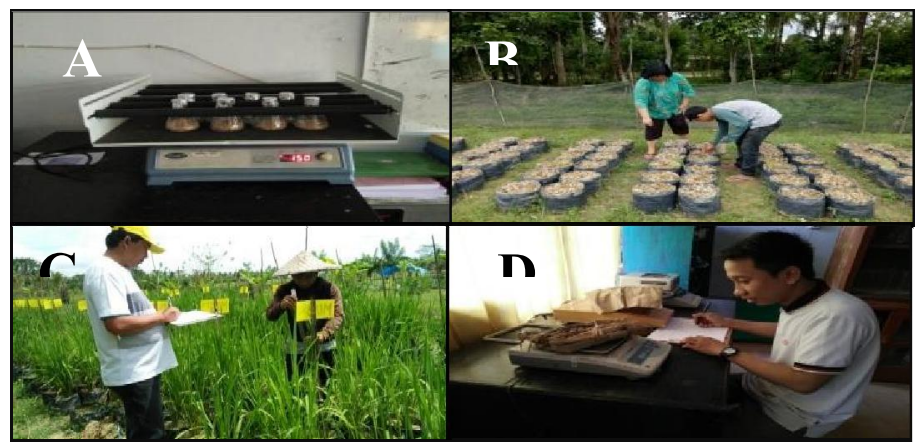

Fig 1. Framework of indegenous rhizobacteria application on local upland rice cultivar; (A) homogenization of rhizobacteria applied on the seeds, (B) plantation,

(C) observation and measurement, (D) plants weighing

\section{Preparation of Growing Media}

The preparation of growing media was done by filling polybag of $20 \mathrm{~cm} \times 40$ $\mathrm{cm}$ using ultisol until the wight reached $10 \mathrm{~kg}$. İt was then continued with sterilization process to kill the microorganism living in the growing media through steaming using sterilization drum for 2 hours. After the growing media was sterilized, 12 polybags for each experimental unit were moved to the field with $30 \mathrm{~cm}$ distance from one to another experimental unit and 1 meter distance for one group to another group. 


\section{Seed Treatment using Rhizobacteria}

All rhizobacteria used was grown in soy agar tryptic and incubated for 48 hours. Colonies grown were suspended in $50 \mathrm{ml}$ sterile aquadest. Before rhizobacteria treatment was given, seeds were washed using sodium hypochlorite $70 \%$ and rinsed using sterile water for 3 times. After the washing, seeds were put into Erlenmeyer containing suspense and covered using alumunium foil. After all seeds filled, suspense was put at the top of shaker for 24 hours (homogenization). When these all were done, seeds were ready to be planted. The plantation was done by planting 4 seeds for each hol and covered with soil.

\section{Fertilization and Harvesting}

Inorganic fertilization was done 3 weeks after the plantation. Inorganic fertilizer used was $\mathrm{CH}_{4} \mathrm{~N}_{2} \mathrm{O}\left(200 \mathrm{~kg} \mathrm{ha}^{-1}\right)$ or equal to $1 \mathrm{~g}$ polybag $^{-1}$, SP-36 $\left(\mathrm{P}_{2} \mathrm{O}_{5}=36 \%\right.$, $\mathrm{S}=5 \%)\left(150 \mathrm{~kg} \mathrm{ha}^{-1}\right)$ or equal to $0.75 \mathrm{~g}^{-}$polybag $^{-1}$ and $\mathrm{KCl}\left(150 \mathrm{~kg} \mathrm{ha}^{-1}\right)$ or equal to $0.75 \mathrm{~g} \mathrm{polibag}^{-1}$. $\mathrm{CH}_{4} \mathrm{~N}_{2} \mathrm{O}$ fertilizer was also given again 5 weeks after the plantation. Upland rice plant was harvested when its physiology is optimum or with the criteria of $90 \%$ of grain turns yellow. The harvesting was done by cutting the upland rice using sickle.

\section{Observation Variable}

Variable observed was vegetative and generative growth parameters. Vegetative growth includes the plant height $(\mathrm{cm})$, amount of leaves (blades), leaves width $\left(\mathrm{cm}^{2}\right)$, number of saplings (sapling), while generative growth includes the blooming age (day), number of productive sapling (sapling), length of panicle $(\mathrm{cm})$, weight of panicle $(\mathrm{g})$, amount of grain per panicle $(\mathrm{g})$, percentage of blank panicle $(\%)$, percentage of filled grain per panicle (\%), weight of one thousand grains (g), production (ton/ha), and harvest index (HI). The observation of local upland rice plant growth was done by using changer of plants height at the age of 12 weeks after the plantation (WAP), width of leaves after 12 weeks of plantation (WAP).Meanwhile, the production (ton/ha) was calculated by converting the weight of 1000 grains per experiemntal unit into the production in ton/ha using the following formula:

$$
\text { Production }=\frac{\text { Welght of } 1,000 \text { grains }(\mathrm{g}) \times 10,000 \mathrm{~m}^{2}}{\text { Plantation distance of } 0.25 \times 0.25 \times 1,000,000}
$$

Harvest index is the comparison between harvesting myield and total biomass calculated using the following formula:

$$
\begin{gathered}
\text { Result of Harvesting } \\
\text { TI }=\text { Total Biomass \% (Salisbury, 1996) } \\
\text { (Total Biomass }=\text { Harvesting result }+ \text { dry weight) }
\end{gathered}
$$

\section{Growth Analysis}

Clean and wind-dried plants were then weighted using analytical scale. İt was then continued by drying using oven and weighted again to know the plants dry 
weight. There were three growth analysis parameters observed. The first is relative growth rate (RGR) $\left(\mathrm{g} \mathrm{g}^{-1} \mathrm{day}^{-1}\right)$ which was calculated using the following formula

$$
\text { RGR }=\frac{\text { In } \mathrm{m}_{2}-\mathrm{In} \mathrm{m}_{1}}{-------------} \text { (Salisbury, 1996) }
$$

Description:

In $\mathrm{m}_{1} \quad=$ Initial weight logarithm

In $\mathrm{m}_{2} \quad$ = Final weight logarithm

$\mathrm{t}_{2}$ dan $\mathrm{t}_{1} \quad=$ Time interval, $\mathrm{t}_{2}=$ second observation time, $\mathrm{t}_{1}=$ first observation time

The second is absolute growth rate (AGR) $\left(\mathrm{g} \mathrm{day}^{-1}\right)$ which was calculated using the following formula:

$$
\text { AGR }=\frac{\mathrm{m}_{2}-\mathrm{m}_{1}}{-\mathrm{t}_{2}-\mathrm{t}_{1}} \text { (Salisbury, 1996) }
$$

Description :

$$
\begin{array}{lll}
\mathrm{m}_{1} & =\text { Initial weight } & \\
\mathrm{m}_{2} & =\text { Final weight } & \\
\mathrm{t}_{2}-\mathrm{t}_{1} & =\text { Time interval } & \mathrm{t}_{2}=\text { second observation time }, \\
& & \mathrm{t}_{1}=\text { first observation time. }
\end{array}
$$

\section{Data Analysis}

Observation result data were analyzed using Anova. If the analysis result indicates $\mathrm{F}_{\text {count }}>\mathrm{F}_{\text {table }}$, then Duncan's multiple range test (DMRT) would be performed at significance level of $\alpha=0.05$. The calculation was done using Statistical Analysis System (SAS) V.9.1.3.

\section{Experimental design}

This study was conducted at Field Laboratory of Faculty of Agriculture, Laboratory of Agrotechnology, and Integrated Laboratory of Universitas Halu Oleo. This study used two factorial designs with four treatment levels. The first factor was designed for different AMF species (10 g/pots): control $\left(\mathrm{M}_{0}\right)$, Acaulospora delicata $\left(\mathrm{M}_{1}\right)$, Septoglomus constrictum $\left(\mathrm{M}_{2}\right)$, and Claroideoglomus etunicatum $\left(\mathrm{M}_{3}\right)$ while the second factor was designed for different concentration of liquid organic fertilizer (mL/pots): control $\left(\mathrm{P}_{0}\right), 150 \mathrm{~mL} /$ pots $\left(\mathrm{P}_{1}\right), 200 \mathrm{~mL} /$ pots $\left(\mathrm{P}_{2}\right)$, and $250 \mathrm{~mL} /$ pots $\left(\mathrm{P}_{3}\right)$. The final experiments were designed in 16 combinations with each three replicates, resulting in 48 experimental units.

\section{Preparation of planting media}

The planting media were ultisols which were sterilized in a furnace with a drum container. The sterilized soils were then air-dried prior experimentation. The sterilized soils were sorted from debris such as twigs, roots, and foliar remnants, loosened and put into polybags measuring $30 \times 40 \mathrm{~cm}$ weighing $\pm 10 \mathrm{~kg}$. 


\section{Preparation of liquid organic fertilizer}

Brown coconut husks were used as the raw materials for preparing the liquid organic fertilizers. Coconut husks were cut into small fragments, then subjected to submerged fermentation in water for 14 days. The fermentation step was stopped when there was a presence of pungent odor or alcoholic scent with reddish fluid indicating that the liquid organic fertilizers were ready to use for further experimentation.

Source of indigenous arbuscular mycorrhizal fungi ( $A M F)$

The AMF strains used in this study were provided by Prof. Dr. Ir. Hj. Husna Faad, M.P maintained in the soils at the Laboratory of Forestry, Faculty of Forestry, Universitas Halu Oleo, Kendari. Inoculation of AMF into soybean plants were adjusted to certain concentration levels. The soybean seeds were firstly soaked in water for 60 $\mathrm{min}$. Three seeds were planted in a polybag containing $10 \mathrm{~g}$ of AMF soils.

\section{Application of liquid organic fertilizers}

The liquid organic fertilizers were applied at the rhizospheric region of soybean plants. The application started after 7 day after sowing (DAS), followed consecutively at 14, 21,28, and 35 DAS. The sequential application were meant to maximize the growth promoting effect from the fertilizers.

\section{Maintenance}

Plant maintenance includes watering, replanting, weeding and thinning. Watering was given 2 times a day (morning and evening) or according to the field conditions. Replanting was done when the plant died or displaying suboptimal growth at 7 DAS. Weeding was done manually by removing the weeds in the polybags. Thinning was done at 14 DAS by pulling out the plants with suboptimal growth, leaving other plants to be maintained until harvesting period.

\section{Harvesting}

The harvesting was done by cutting the base of the soybean stem which have undergone physiological ripening. The signs of harvest-ready soybean plants were having the most of leaves (90-95\%) turning brownish yellow and then shed, the stems dried out and were slightly brownish yellow in color.

\section{Experimental variables}

The variables observed in this study were plant height $(\mathrm{cm})$, observed by measuring the soybean plants from the stem base until the longest plant tips. Number of leaves was observed by counting the number of blades that have opened perfectly. Leaf area $\left(\mathrm{cm}^{2}\right)$ was measured from the length of the leaves in proportion to the width on the upper, middle, and lower side of leaves using the following formula:

\section{$L A=L x W x G$}

Where:

$$
\begin{array}{ll}
L A & =\text { Leaf area }\left(\mathrm{cm}^{2}\right) \\
L & =\text { Leaf length }(\mathrm{cm}) \\
W & =\text { Leaf width }(\mathrm{cm})
\end{array}
$$


$C \quad=$ Constant (0.74) [10]

The stem diameter $(\mathrm{cm})$ was measured using calipers. All variables were measured at $14,28,42$, and 56 DAS.

\section{Data analysis}

Experimental data were analyzed using an analysis of variance (ANOVA). If the analysis resulted in which $F_{\text {count }}>F_{\text {table }}$, then multiple comparisons were performed using Duncan's multiple range test at $95 \%$ level of significance.

\section{RESULT AND DISCUSSION}

\section{Plant Height}

Indigenous rhizobacteria treatment is able to increase local upland rice plants height. Both Paebiu Kolopua and Pae Wuna cultivars indicated that the KLKU02 isolate treatment from North Kolaka (R2) gave highest average height compared to KNW11 (R3), KNS11 (R1) isolates and control (R0) (Figure 2).
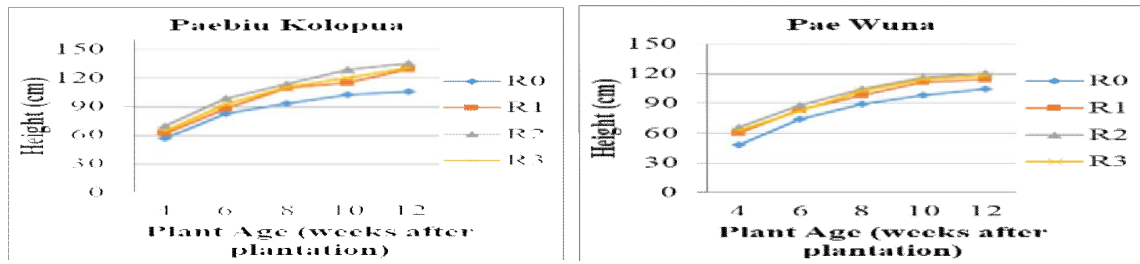

Fig 2. Dynamics of local upland rice plant height growth on cultivar and indigenous rhizobacteria treatment

DMRT test results showed that the interaction between cultivar and indegenous rhizobacteria treatments significantly affected the plants height at the age of 12 weeks after the plantation. The effect of the interaction between cultivar and indigenous rhizobacteria on plnats height observation at the age of 12 weeks after plantation indicated that the interaction of Paebiu Kolopua cultivar and KLKU02, KNW11, KNS11 interaction treatment as well as treatment without indigenous rhizobacteria was significantly different from Pae Wuna andt KLKU02, KNW11, KNS11 isolates. Furthermore, the shortest plants height was indicated by treatment without indigenous rhizobacteria. İn this case, the increase of additional height reached 29.22\% (Table 1).

Table 1. DMRT test result of the effect of interaction between cultivars and indigenous rhizobacteria on local upland rice plants height $(\mathrm{cm})$ at the age of 12 weeks after plantation

\begin{tabular}{|l|c|l|r|l|}
\hline \multirow{2}{*}{ Treatment } & \multicolumn{4}{|c|}{ Cultivars } \\
\cline { 2 - 5 } & \multicolumn{5}{|c|}{ Paebiu Kolopua } & Pae Wuna \\
\hline Control & 12 weeks after plantation \\
\hline KNS11 isolate & $106.07 \mathrm{p}$ & $\mathrm{c}$ & $104.62 \mathrm{q}$ & $\mathrm{c}$ \\
\hline KLKU02 isolate & $129.77 \mathrm{p}$ & $\mathrm{b}$ & $114.58 \mathrm{q}$ & $\mathrm{b}$ \\
\hline KNW11 isolate & $135.19 \mathrm{p}$ & $\mathrm{a}$ & $120.31 \mathrm{q}$ & $\mathrm{a}$ \\
\hline
\end{tabular}


Description: numbers followed by the same letters on the same column (a-c) and same line (p-q) is not significantly different on DMRT $\alpha=0.05$

Plant height is correlated with the quantity, length, and even weight of plant roots. Current research reported that Paebiu Kolopua cultivar and KLKU02 isolate treatments had more and longer roots so that this treatment was better than other treatments (Figure 3 and Figure 4). It is suspected that the rhizobacteria isolated from KLKU02 was able to adapt to ultisol and produced higher IAA hormones than other isolates. This is in line with the opinion stated [22], that IAA hormone has the ability to control many aspects of plant growth and development such as vascular tissue differentiation, root elongation, lateral root initiation, and plant fruit development and maturation. A previous research reported that inoculation of maize with $P$. stutzeri A1501 generated a considerable increase in shoot and root weight $(20.2 \%$ and $31.2 \%$, respectively) when planted on sterilized soil, compared to the control without A1501 [23].

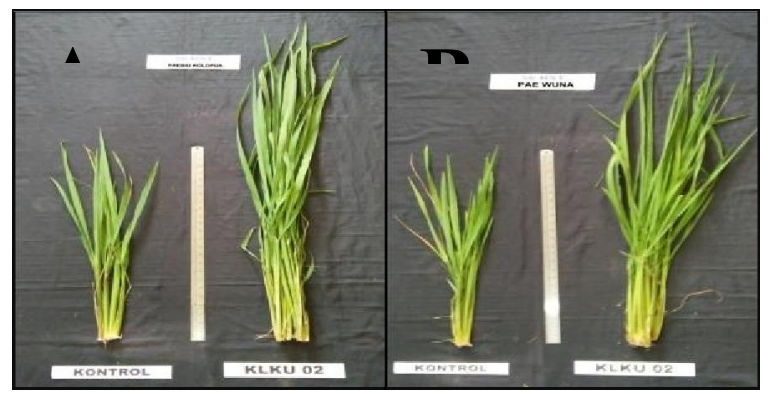

Fig 3. Local upland rice height after KLKU02 isolate treatment; (A) Paebiu Kolopua cultuvar, (B) Pae Wuna cultivar. Note: kontrol= control

KLKU02 isolate treatment was able to play an active role in increasing plant growth through its function as a producer of IAA growth hormone and $\mathrm{N}$ fixation from the air and was able to release $\mathrm{Al}$ bonds to $\mathrm{P}$ elements so that $\mathrm{P}$ elements could be available to plants. This is in line with the opinion stated before [24], that the group of plant growth triggering rhizobacteria or Plant Growth Promoting Rhizobacteria (PGPR) from the Bacillus sp. able to produce IAA hormone and dissolve phosphate, and able to fix nitrogen from the air.Ultisol exhibits serious nutrient deficiencies [25]. Thus, sustainable agricultural practice is urgently required to fertilize soil and maximize crop productivity in Ultisols.

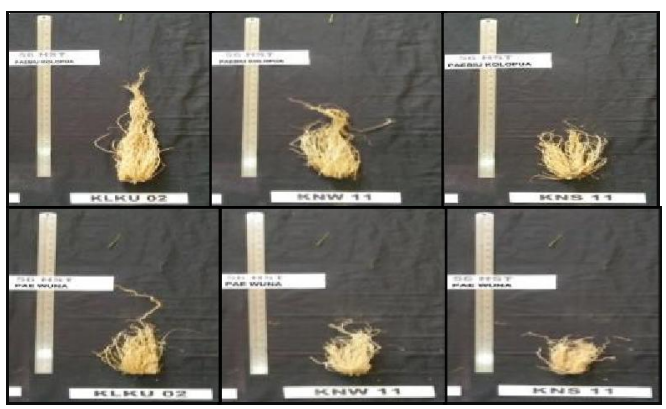


Fig 4. Pae Wuna and Paebiu Kolopua cultivar roots after local rhizobacteria treatment. KLKU (North Kolaka), KNW (Konawe), KNS (South Konawe)

The availability of IAA hormone for plants will lead to better root development so that the roots will be able to absorb other nutrients, both macro and micro thus they can be utilized by plants properly [26]. As supported by the previous research results conducted by Aw et al., treatment of rhizobacteria Pseudomonas mosselii S6, Bacillus thuringiensis S7, Bacillus sp. JBS-28 which has IAA activity can promote Rice growth (grain production increased by $10.50-51.30 \%$ under greenhouse conditions and 4.83-9.16\% in paddy fields) and damage in rice were both decreased. Therefore, the treatment of rhizobacteria Pseudomonas spp. must get an important part in its application in Ultisols, to maintain soil fertility and boost crop output.

Generative Growth

Number of Productive Saplings

The interaction of Paebiu Kolopua cultivar treatment and KLKU02 isolate showed the highest number of productive saplings which was significantly different from the Pae Wuna cultivar and KLKU02 isolate treatment compared to other treatments (Table 2). The productivity is affected by the metabolic activity of $P$. Fluorescens KLKU02. Pratiwi et al reported that $P$. fluorescens concentrations of 109 cfu/mL substantially improved Fe availability in soil by $34.75 \%$ to the control [27]. The element $\mathrm{Fe}$ is plentiful in the earth's layers, yet it is frequently unavailable to plants due to the colloidal mineral soil adsorbtion [28], it means that P. Fluorescens has significant role in assisting the plants to absorb $\mathrm{Fe}$ in the soil for the growth.

Table 2. DMRT test results of the effect of interaction between cultivar and indegenous rhizobacteria on the amount of productive saplings on local upland rice

\begin{tabular}{|c|c|c|c|c|c|}
\hline \multirow{3}{*}{$\begin{array}{l}\text { Treatment } \\
\text { Control }\end{array}$} & \multicolumn{4}{|c|}{ Cultivars } & \multirow{3}{*}{$\begin{array}{c}\operatorname{DMRT}(\mathrm{R}) \\
\alpha=0.05 \\
\end{array}$} \\
\hline & \multicolumn{2}{|c|}{ Paebiu Kolopua } & \multicolumn{2}{|c|}{ Pae Wuna } & \\
\hline & $5.04 \mathrm{p}$ & $\mathrm{d}$ & $4,83 \mathrm{q}$ & $\mathrm{d}$ & \\
\hline KNS11 isolate & $8.37 \mathrm{p}$ & $\mathrm{c}$ & $7,98 \mathrm{q}$ & $\mathrm{c}$ & $2=0.642$ \\
\hline KLKU02 isolate & $12.33 \mathrm{p}$ & $\mathrm{a}$ & $10,11 \mathrm{q}$ & $\mathrm{a}$ & $3=0.673$ \\
\hline KNW11 isolate & $11.61 \mathrm{p}$ & $\mathrm{b}$ & $8,75 \mathrm{q}$ & $\mathrm{b}$ & $4=0.692$ \\
\hline \multicolumn{6}{|c|}{$\operatorname{DMRT}(\mathrm{V}) \alpha=0.05 \quad 2=0.454$} \\
\hline
\end{tabular}

Description: numbers followed by the same letters on the same column (a-d) and same line (p-q) is not significantly different on DMRT $\alpha=0.05$

Inorganic phosphates can be solubilized by bacteria in many ways [29]. The transfer of $\mathrm{H}^{+}$to the outer surface of bacterium cells in return for cation uptake may be an acid-independent route for phosphate solubilization [30], although phosphates are mostly released as a result of soil acidification through organic acid discharge. $P$. fluorescens suspension spraying to rice plants can increase the number of rice saplings [31]. 


\section{Amount of Grain Per Panicle}

The treatment of Paebiu kolopua cultivar and KLKU02 isolate showed the highest mean value which was significantly different from the treatment of Pae Wuna cultivar and KLKU02 isolate (Table 3). Treatment using KLKU02 isolate showed the highest value for both rice cultivars.

Table 3. DMRT test results on the effect of interaction between cultivars and indigenous rhizobacteria on the amount of grain per panicle (grain) of local upland rice

\begin{tabular}{|c|c|c|c|c|c|}
\hline \multirow{3}{*}{$\begin{array}{l}\text { Treatment } \\
\text { Control }\end{array}$} & \multicolumn{4}{|c|}{ Cultivars } & \multirow{3}{*}{$\begin{array}{c}\text { DMRT (R) } \\
\alpha=0.05\end{array}$} \\
\hline & \multicolumn{2}{|c|}{ Paebiu Kolopua } & \multicolumn{2}{|c|}{ Pae Wuna } & \\
\hline & $119.20 \mathrm{p}$ & d & $104.33 \mathrm{q}$ & d & \\
\hline KNS11 isolate & $192.73 \mathrm{p}$ & $\mathrm{c}$ & $182.89 \mathrm{q}$ & $\mathrm{c}$ & $2=7.703$ \\
\hline KLKU02 isolate & $295.53 \mathrm{p}$ & $\mathrm{a}$ & $229.00 \mathrm{q}$ & $\mathrm{a}$ & $3=8.071$ \\
\hline KNW11 isolate & $274.67 p$ & $\mathrm{~b}$ & $203.44 \mathrm{q}$ & $\mathrm{b}$ & $4=8.298$ \\
\hline
\end{tabular}

Description: numbers followed by the same letters on the same column (a-d) and same line (p-q) is not significantly different on DMRT $\alpha=0.05$

These results indicate that the addition of KLKU02 inoculants to the fertilization is recommended to increase rice production by increasing the number of grains per panicle (Figure 5). This result was possible because of the ability of KLKU02 inoculants to produce auxin phytohormones and dissolve soil phosphate, and fix nitrogen from the air for plant growth and the addition of nutrients could be allocated for the generative phase of plants.

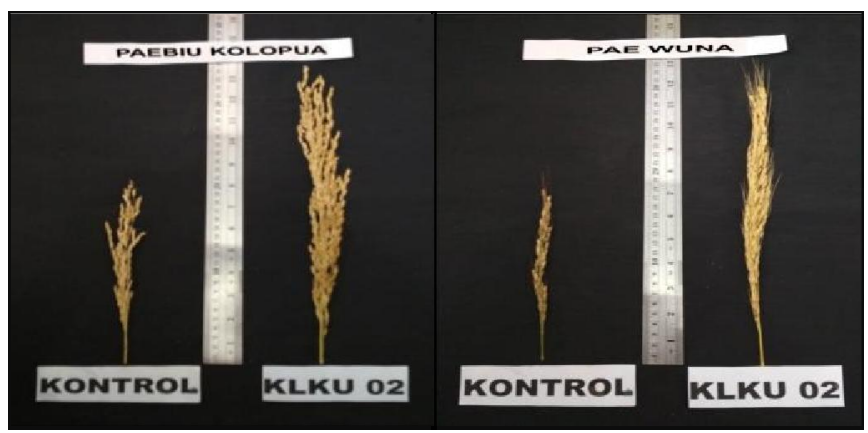

Fig 5. Results of Local Upland Rice After Treatment of Indigenous Rhizobacteria. Note: kontrol= control

Ramette et al. [32] reported that due to its capacity to create auxin, phosphate solubilization, and siderophore synthesis, Pseudomonas are plant growth-promoting bacteria. Pseudomonas spp. have been shown to improve seed germination, root development, plant growth, and yield in a variety of crops when used as seed or soil inoculants [33]. Previous research reported that P. fluorescens (strain P1, P3, P8, and P14) had a significant amount of work of 1-aminocyclopropane-1-carboxylate (ACC) 
deaminase, auxin synthesis, ability to solubilize phosphate and siderophore production [34].

\section{Production (ton/ha)}

The interaction between cultivars and indigenous rhizobacteria on the production of local upland rice showed that the highest production percentage was found in the Paebiu Kolopua cultivar and KLKU02 isolate (5.19 tons ha-1) and significantly different from all treatments, while the lowest production was shown in the Pae cultivar treatment of Pae Wuna and without treatment of indigenous rhizobacteria (control) which were 3.16 tons ha-1 (Table 4). Pseudomonas spp. inoculated Triticum aestivum showed an increase in biomass output and phosphate absorption, among other things [35].

Table 4. DMRT test results of the Effect of interaction between cultivars and indigenous rhizobacteria on the production (ton ha-1) of local upland rice

\begin{tabular}{|c|c|c|c|c|c|}
\hline \multirow{3}{*}{$\begin{array}{l}\text { Treatment } \\
\text { Control }\end{array}$} & \multicolumn{4}{|c|}{ Cultivars } & \multirow{3}{*}{$\begin{array}{c}\text { DMRT (R) } \\
\alpha=0.05\end{array}$} \\
\hline & \multicolumn{2}{|c|}{ Paebiu Kolopua } & \multicolumn{2}{|c|}{ Pae Wuna } & \\
\hline & $3.32 \mathrm{p}$ & d & $3.16 \mathrm{q}$ & $\mathrm{d}$ & \\
\hline KNS11 isolate & $4.27 \mathrm{p}$ & $\mathrm{c}$ & $4.14 \mathrm{q}$ & $\mathrm{c}$ & $2=0.105$ \\
\hline KLKU02 isolate & $5.19 \mathrm{p}$ & $\mathrm{a}$ & $4.45 \mathrm{q}$ & $\mathrm{a}$ & $3=0.110$ \\
\hline KNW11 isolate & $4.58 \mathrm{p}$ & $\mathrm{b}$ & $4.40 \mathrm{q}$ & $\mathrm{b}$ & $4=1.113$ \\
\hline
\end{tabular}

Description: numbers followed by the same letters on the same column (a-d) and same line (p-q) is not significantly different on DMRT $\alpha=0.05$.

\section{Harvest index}

Independent treatment of indigenous rhizobacteria gave a very significant effect on the harvest index parameters, the treatment of KLKU02 isolates showed the highest harvest index values which were significantly different from the treatment of KNW11 isolates, KNS11 isolates and without indigenous rhizobacteria (control) (Table 5). Harvest Index (\%) significantly increased by isolate KLKU02 compared with KNW11, KNS11, and uninoculation.

Table 5. DMRT test results Independent effect of cultivar treatment and indigenous rhizobacteria on local upland rice harvest index

\begin{tabular}{|c|c|c|c|c|}
\hline \multirow{2}{*}{ Treatment } & \multicolumn{2}{|c|}{ Cultivars } & \multirow{2}{*}{ Average } & \multirow{2}{*}{$\begin{array}{c}\operatorname{DMRT}(\mathrm{R}) \\
\alpha=0.05\end{array}$} \\
\hline & Paebiu Kolopua & Pae Wuna & & \\
\hline Control & 20.39 & 17.61 & $19.00 \mathrm{~d}$ & \\
\hline KNS11 isolate & 27.90 & 24.29 & $26.10 \mathrm{c}$ & $2=1.487$ \\
\hline KLKU02 isolate & 36.38 & 32.62 & $34.50 \mathrm{a}$ & $3=1.558$ \\
\hline KNW11 isolate & 34.45 & 28.78 & $31.61 \mathrm{~b}$ & $4=1.602$ \\
\hline Average & $29.78 \mathrm{a}$ & $25.83 \mathrm{~b}$ & $\operatorname{DMRT}(\mathrm{V}) \alpha=0.05$ & $2=1.051$ \\
\hline
\end{tabular}


Description: numbers followed by the same letters on the same column (a-d) and same line (p-q) is not significantly different on DMRT $\alpha=0.05$.

The positive effect of KLKU02 might be caused by PGPR (Plant Growth Promoting Rhizobacteria) traits, which might be effective in improving the seed germination rate, plant growth and harvest index. Through the phenomenon of Induced Systemic Resistance (ISR) in rice plants, utilizing PGPR bacteria genus Pseudomonas is important role of boosting growth bacteria for plants is to decrease or eliminate the detrimental impacts of disease agents [36,37].

\section{Relative Growth Rate}

The effect of interaction between the treatment of cultivars and indigenous rhizobacteria on the relative growth rate of local upland rice plants aged 42-56 showed that the treatment of Paebiu Kolopua cultivar and KLKU02 isolate gave the highest value (0.107) and was significantly different from all treatments. The increase in plant growth rate was caused by the total dry weight of plants produced by plants per unit time. The effectiveness of Pseudomonas fluorescens KLKU02 treatment had an effect on plant growth. has been proven to colonize the roots of diverse plants and enhance the height, flower number, fruit number, and total fruit weight of tomato plants when isolated from the roots of graminaceous plants [38].

\section{CONCLUSION}

The interaction of cultivar treatment and indigenous rhizobacteria has the ability to improve the upland rice growth and results as indicated by an increase in plant height, relative growth rate, and a very significant effect on the number of productive saplings, number of grain per panicle, production and harvest index. The interaction between Paebiu Kolopua cultivar and KLKU02 isolate treatments resulted in the highest production of 5.19 tons ha-1 with an increase in production of $56.32 \%$ compared to the control. Pseudomonas fluorescens KLKU02 is an indigenous rhizobacteria that can be suggested as a stimulator for increasing local upland rice production of Paebiu kolopua and Pae Wuna cultivars.

\section{REFERENCES}

[1] Savci, S. 2012. Investigation of effect of chemical fertilizers on environment. $\boldsymbol{A P C B E E}$ Procedia 1: 287-292.

[2] Singh, A., A. Jain, B.K. Sarma, R.S. Upadhyay and H.B. Singh. 2013. Rhizosphere microbes facilitate redox homeostasis in Cicer arietinum against biotic stress. Annals of Applied Biology 163: 33-46.

[3] Jain, A., A. Singh, S. Singh and H.B. Singh. 2013. Microbial consortium-induced changes in oxidative stress markers in pea plants challenged with Sclerotinia sclerotiorum. Journal of Plant Growth Regulation 32: 388-398.

[4] Callan, N.W., D.E. Mathre, J.B. Miller and C.S. Vavrina. 1997. Biological seed treatments: factors involved in efficacy. HortScience 32: 179-183. 
[5] Pill, W.G., C.M. Collins, B. Goldberger and N. Gregory. 2009. Responses of non-primed or primed seeds of 'Marketmore 76'cucumber (Cucumis sativus L.) slurry coated with Trichoderma species to planting in growth media infested with Pythium aphanidermatum. Scientia Horticulturae 121: 54-62.

[6] Dobbelaere, S., J. Vanderleyden and Y. Okon. 2003. Plant growth promoting effects of diazotrophs in the rhizosphere. Critical Reviews in Plant Sciences 22: 107-149.

[7] Hahm, M.S., M. Sumayo, Y.J. Hwang, S.A. Jeon, S.J. Park, J.Y. Lee, J.H. Ahn, B.S. Kim, C.M. Ryu, and S.Y. Ghim. 2012. Biological control and plant growth promoting capacity of rhizobacteria on pepper under greenhouse and field conditions. Journal of Microbiology 50: 380-385.

[8] Keswani, C., S.P. Singh and H.B. Singh. 2013. A superstar in biocontrol enterprise: Trichoderma spp. Biotech Today An International Journal of Biological Sciences 3: 27-30.

[9] Contreras-Cornejo, H.A., L. Macha-Rodrhguez and A. Herrera-Estrella. 2014. The 4phosphopantetheinyl transferees of Trichoderma virens plays a role in plant protection against Botrytis cinerea through volatile organic compound emission. Plant and Soil 379: 261-274.

[10] Mahmood, A., O.C. Turgay, M. Farooq and R. Hayat. 2016. Seed biopriming with plant growth promoting rhizobacteria: A review. FEMS Microbiology Ecology 92: 1-14.

[11] Harman, G.E. and A.G. Taylor. 1988. Improved seedling performance by integration of biological control agents at favorable $\mathrm{pH}$ levels with solid matrix priming. Phytopathology, 78: 520-525.

[12] Jensen, B., I.M. Knudsen, M. Madsen, and D.F. Jensen. 2004. Biopriming of infected carrot seed with an antagonist, Clonostachys rosea, selected for control of seedborne Alternaria spp. Phytopathology 94: 551-560.

[13] Zahir, Z., A. Munir, H. Asghar, B. Shaharoona and M. Arshad. 2008. Effectiveness of rhizobacteria containing ACC deaminase for growth promotion of peas (Pisum sativum) under drought conditions. Journal of Microbiology and Biotechnology 18: 958-963.

[14] Bano, Q., N. Ilyas, A. Bano, N. Zafar, A. Akram and F. Hassan. 2013. Effect of Azospirillum inoculation on maize (Zea mays L.) under drought stress. Pakistan Journal of Botany 45: 13-20.

[15] Choudhary, D.K., A. Kasotia, S. Jain, A. Vaishnav, S. Kumari, K.P. Sharma and A. Varma. 2016. Bacterial mediated tolerance and resistance to plants under abiotic and biotic stresses. Journal of Plant Growth Regulation 35: 276-300.

[16] Zarei, T., A. Moradi, S.A. Kazemeini, H. Farajee and A. Yadavi. 2019. Improving sweet corn (Zea mays L. var saccharata) growth and yield using Pseudomonas fluorescens inoculation under varied watering regimes. Agricultural Water Management 226: 105757.

[17] Park, Y.S., S. Dutta, M. Ann, J.M. Raaijmakers and K. Park. 2015. Promotion of plant growth by Pseudomonas fluorescens strain SS101 via novel volatile organic compounds. Biochemical and Biophysical Research Communications 461: 361-365.

[18] Gou, W., L. Tian, Z. Ruan, P. Zheng, F. Chen, L. Zhang, Z. Cui, P. Zheng, Z. Li and M. Gao. 2015. Accumulation of choline and glycinebetaine and drought stress tolerance induced in maize (Zea mays) by three plant growth promoting rhizobacteria (PGPR) strains. Pakistan Journal of Botany 47: 581-586. 
[19] Sadimantara, G.R. and Muhidin. 2012. Characterization of Drought Resilience Plasma Nutfah Rice Gogo Local Origin Southeast Sulawesi. Jurnal Agroteknos 2: 51-56.

[20] Wahyuni, T. 2015. Seed Treatment With PEG 6000 For Early Estimation of Local Gogo Rice Tolerance Against Drought. Thesis. Universitas Halu Oleo. Kendari.

[21] Badan Pusat Statistik. (2016). Sulawesi Tenggara dalam Angka (Edisi 1 Juli 2016). Kendari.

[22] Maheswari, U.T., K. Anbukkarasi, T. Hemalatha and K. Chendrayan. 2013. Studies on phytohormone producing ability of indigenous endophytic bacteria isolated from tropical legume crops. International Journal of Current Microbiology and Applied Sciences 2: $127-136$.

[23] Ke, X., S. Feng, J. Wang, W. Lu, W. Zhang, M. Chen and M. Lin. 2018. Effect of inoculation with nitrogen-fixing bacterium Pseudomonas stutzeri A1501 on maize plant growth and the microbiome indigenous to the rhizosphere. Systematic and Applied Microbiology 42: 248-260.

[24] Sutariati, G.A.K., T.C. Rakian, Agustina, N. Sopacua, L. Mudi and M. Haq. 2014. Study of potential rizobacterial growth boosters isolated from healthy rice rizosfers. Jurnal Agroteknos, 4: 71-77.

[25] He, L., X. Zhao, S.Q. Wang and G.X. Xing. 2016. The effects of rice-straw biochar addition on nitrification activity and nitrous oxide emissions in two Oxisols. Soil $\boldsymbol{\&}$ Tillage Research 164: 52-62.

[26] Lestianingrum, A.G.M., I.G.N. Raka, dan I.D.N. Nyana. 2017. Test Capabilities some Isolate Rhizobacteria for Enhancing the Growth and Yield of Soybean (Glycine max L. Merill). E-Jurnal Agroekoteknologi Tropika 6: 31-40.

[27] Pratiwi, H., N. Aini and R. Soelistyono. 2016. Effects of Pseudomonas fluorescens and sulfur on nutrients uptake, growth and yield of groundnut in an alkaline soil. Journal of Degraded and Mining Lands Management 3: 507-516.

[28] Ammari, T. and K. Mengel. 2006. Total soluble Fe in soil solutions of chemically different soils. Geoderma, 136: 876-885.

[29] Alori, E.T., B.R. Glick and O.O. Babalola. 2017. Microbial phosphorus solubilization and its potential for use in sustainable agriculture. Frontiers in Microbiology 8: 971.

[30] Rodríguez, H. and R. Fraga. 1999. Phosphate solubilizing bacteria and their role in plant growth promotion. Biotechnology Advances 17: 319-339.

[31] Fitriatin, B.N. and T. Simarmata. 2005. Effect of seed treatment with kinetin and suspension of phosphate solubilizing phytohormone producing bacteria to the growth and yield of upland rice. Agrikultura 16: 84-88.

[32] Ramette, A., Y. Moenne-Loccoz and G. Defago. 2006. Genetic diversity and biocontrol potential of fluorescent Pseudomonas producing phloroglucinols and hydrogen cyanide from Swiss soils naturally suppressive or conducive to Thielaviopsis basicola- mediated black root rot of tobacco. FEMS Microbiology Ecology 55: 369-381.

[33] Khan, M.R., S. Altaf, F.A. Mohiddin, U. Khan and A. Anwer. 2009. Biological control of plant nematodes with phosphate solubilizing microorganisms. In: Khan, M.S., Zaidi, A. (Eds.), Phosphate Solubilizing Microbes for Crop Improvement. Nova Science Publishers, Inc., New York, pp. 395-426. 
[34] Akhgar, A., K. Khavazi and N. Khakipoor. 2011. Isolation, identification and effectiveness of ACC deaminase producing rhizobacteria on the alleviation of salinity stress effects on canola growth. Journal of Water and Soil Science 25: 29-41.

[35] Ma, Y., M. Rajkumar, Y. Luo and H. Freitas. 2011. Inoculation of endophytic bacteria on host and non-host plants-effects on plant growth and $\mathrm{Ni}$ uptake. Journal of Hazardous Materials, 195: 230-237.

[36] Malleswari, D. and G. Bagyanarayana. 2013. In vitro screening of rhizobacteria isolated from the rhizosphere of medicinal and aromatic plants for multiple plant growth promoting activities. Journal of Microbiology and Biotechnology Research 3: 84-91.

[37] Sivakumar, T., T. Shankar, P. Vijayabaskar and S. Rama. 2012. Plant growth promoting activity of nickel tolerant Bacillus cereus TS1. Journal of Agricultural Technology 8: 2101-2113.

[38] Minorsky, P.V. 2008. On the inside. Plant Physiology 146: 323-324. 